\title{
HARRY'S CODE
}

\author{
an interview with Harry Collins
}

by Robert L. Jomisko

While attending a conference in Budapest in May, I caught up with Harry Collins in Memento Park; an open-air museum filled several dozen statues, busts and plaques from the Communist era. According to the Hungarian architect Ákos Eleód, who designed it, "the park is about dictatorship. And at the same time, because it can be talked about, described, built, this park is about democracy. After all, only democracy is able to give the opportunity to let us think freely about dictatorship." In retrospect, it seemed a fitting location for the interview. As many of our readers are no doubt already aware, Collins has for at least ten years been engaged in discussions about social aspects of science and democracy. In efforts to impose what some have described as restrictions on public engagement with expertise, there are those who have labeled his proposals 'illiberal' and 'undemocratic'. Others have viewed them as an attempt to ensure expertise is not lost when engaging the public in decision-making. Ever since his early works on knowledge diffusion in the 1970s, Collins has kept reinventing himself. And with an advanced grant from the European Research Council, he shows no signs of slowing down anytime soon. 
Harry Collins, when did you first realize you wanted to become a social scientist?

That's too early in my life, but I started my sociology degree in 1964 . So, that's the answer, started in 1964. That's when I realized.

\section{And how did you realize?}

It's a series of accidents. It doesn't matter; it's too far back, let's go a little further forward.

\section{How has your perspective on STS evolved throughout your career?}

You can say my STS career began in 1970 or ' 71 , when I was doing my master's degree at the University of Essex. My degree was based on the London University syllabus, which had a lot of philosophy in it. I had read a lot of philosophy of social science, in particular Peter Winch's The Idea of a Social Science, Thomas Kuhn's Structure of Scientific Revolutions, and Karl Popper, and I was really interested in the philosophy of science and philosophy of social science. Then when I was at the University of Essex doing my master's degree I had to do a dissertation, and I thought it would be interesting to go into science laboratories. So, I asked around and I found that in the physics laboratory in Essex University, where I was, were building a new kind of laser called the TEA laser - a Transversely Excited Atmospheric pressure laser. For my dissertation I decided I would do an information diffusion study of this laser. However, I knew I was going to do the study differently to the way it had been done before. It was going to be a knowledge diffusion study rather than an information diffusion study. With ideas from Kuhn and Wittgenstein, I thought I would study the ability to learn to build a laser. It was going to be like learning a language rather than gathering a set of discrete pieces of information that could be read from a book, because I had the idea of paradigm and I had the idea of form of life from Wittgenstein. I wanted to see this as a spreading, diffusing form of life, rather than as people gathering discrete pieces of information from one another.

I went around the country interviewing people who had managed to make one of these lasers work and I was particularly interested in who and how they spoke to other people, whom they contacted and so forth. What I discovered was that the only people who succeeded in building the laser and making it work were people who had social contact with other people who had a machine that worked. Then there were other people who tried to build the laser, but who weren't able to make it work. You could tell whether they worked or not because the laser was a very, very powerful instrument. It would produce a beam of infrared radiation when it was working and you could point it on a lump of concrete, and it would make the concrete smoke. So, you knew if you had your laser working or not.

Only the people able to make it work were those who had prolonged social contact with people who had a working laser. The contact could be by spending some time in their lab, or having some member of their team go up there and spend some time in their lab. That was my discovery and I wrote this up and said, "this shows that learning to build a TEA laser is like learning a language, not like learning discrete pieces of information, because you can only learn it through social contact in the way you learn a language." The title of the thesis was The Sociology of the $\mathrm{CO}_{2}$ Laser. I remember people laughing or pointing to this title and grinning, because no one had ever seen a title like that before. How could you have a sociology of a $\mathrm{CO}_{2}$ laser?

That's how I began in STS. I then became a Ph.D. student at the University of Bath, and what I decided to do was some comparative studies. I would finish the TEA laser study by continuing to trace the pattern of diffusion of the ability to build TEA lasers. tracing it from where it had all started in Canada, where Jacques Beaulieu had built the first one, and chasing it through all the American laboratories who had built one, and all the way back to the UK, so that I would complete the study and see if the findings held up. Whilst I was doing this I also thought I should compare it with some other areas of science and do similar diffusion studies, but in more competitive areas to see if the knowledge diffusion worked differently. The two areas I picked were parapsychology and the detection of gravitational waves, because I had read articles in the New Scientist that showed that both of these were quite controversial areas. Then I went to America, bought an old car and drove 7000 miles around America interviewing scientists in these fields and also in another field called the theory of amorphous semiconductors - which my supervisor suggested I should do, so I could have a theoretical field as well. That never came to anything, because I could never understand the physics.

At the end of my journey, while I was driving across Nevada in my old car - a big white Ford Galaxy, which cost me \$200 - I suddenly realized that my study was completely flawed, and was a complete failure. The trick with the TEA laser study was to know whether the laser was working or not, and you could tell whether it was working because the infrared beam would make concrete smoke, whereas with something like the gravitational wave study, we didn't know what the gravitational wave detector was supposed to do when it was working. Should it be detecting gravity waves or shouldn't it be detecting gravity waves? And I thought to myself; how could I have made such a terrible mistake? I've completely wasted all the money from my Ph.D., and I'm a failure. After about half an hour it occurred to me that this was much more interesting than the original study, because if I don't know whether the gravitational radiation detector is working or not, neither do the scientists. How do they decide if it is working or not? From this grew the idea of the experimenter's regress and the relativistic approach to the Sociology of Scientific Knowledge, as my work in the 'Bath School', with its 'the empirical program of relativism', became known. I later discovered there was similar work already going on in Edinburgh - but more philosophical rather than empirical. 
That was the start of what I did, and it eventually became a book called Changing Order, which wasn't published until 1985. In the meantime I had done a completely different study on Uri Geller and spoon bending children, which was published in a book in 1982. If I had any brains I would have published the second book first. That's how I started to become a sociologist of science; a very relativistic sociology of science, and it was as one of the founders, I think, of the Sociology of Scientific Knowledge, SSK, and was the first person to do any empirical studies in the Sociology of Scientific Knowledge. So, that's how I started, and you asked me has my perspective changed, and the answer is no, not at all.

What are your thoughts on the development of STS from then to now in relation to the political turn we have seen in STS in recent years?

Well, you tell me what you mean by the 'political turn'?

\section{There seems to have been a shift from focusing on laborato- ries to a focus on the political arena.}

I've always been against it. In fact, I think it was when Wiebe Bijker was President of the Society for Social of Studies. During one of the meetings I remember him saying "we must now move down the boulevard of politics." - that is what is happening to Science Studies now. I stood up and said, "no we don't want to move down the boulevard of politics. There are many, many institutions, which are designed to do politics. Politics are everywhere, but social studies of science have a unique role, and we should stick with the unique role, and we should do it as scientists." Because scientists have a special warrant for getting people to believe what they say is true, and politics is too easy. All you have to do to be a successful politician is to say the same as everyone else wants to believe. But to be a successful scientist you have to say things that other people don't want to believe, and convince them that it is true. I said I disapprove totally of the Society (for Science and Technology) becoming more political. I would like to see this not happen, and so I was always against it. You're going to point out to me in a minute, that in recent years I've become a little more political myself, and it is true. But that is my main view about the politicized tradition of STS. I think it has spoiled STS.

\section{For those not familiar with the Third Wave of Science Studies} could you give us a little background?

Earlier on, I said my view hasn't changed at all, and I was slightly surprised that you had no reaction to this. Because I would have expected you to say "what do you mean your view hasn't changed at all? You're notorious for changing your view and turning from a radical relativist in the analysis of science to somebody who says you must have a realist theory of expertise, and we must favor science," aren't you going to say that?

Robert Evans: No, he can ask his own questions.

OK. But since you brought it up, Harry, I'Il let you answer it. The answer is that it isn't a change. It's not a change in the view about the nature of the world. It's just a change in where one turns one attention. I said in something published recently that if I look that way, I can see one sort of thing. If I look that way, by turning around, to look behind me, I can see another thing. But those things aren't in tension. It's just a way of turning your attention from front to behind. What I've done more recently started with a notorious paper called "The Third Wave of Science Studies", which was published in 2002. That turned my colleague Robert Evans and my attention to a different kind of question. The different kinds of question are: How can you still value science? Do you still value science in spite of all the analysis we've learned under what we call Wave Two of Science Studies, all the relativist analysis, all the experiments regress, and all these other things? How can we still value science before it disappears completely under our onslaught?

For those not familiar with the Third Wave of Science Studies article could you give us a little background? Why did you and Rob decide to write the 2002 paper?

The paper in 2002 represented a turn of attention to a different thing, which is how can one still value science or expertise in spite of all the things we have accomplished in Wave Two; all the relativism, the experiments, the regress, so on and so forth? The reason why I was led to turn my attention to this was because I worried people were arguing science into a worthless position. On the other hand there were some people asking sensible questions like what relativism has to offer someone who wants to argue with a man from the South African townships, who says he will cure his AIDS by having sex with a virgin. Presumably we can assume that having sex with a virgin is not a good idea to cure AIDS, but how are we going to argue this if we have no scientific proof? Especially if the grounds for expertise have been dissolved. The Third Wave of Science Studies paper was an attempt to find a way of showing that it is still possible to value science despite all the things that we had discovered in Wave Two. A lot of people thought it was a way of turning one's back on Wave Two, but it was not. The main trick was to shift attention from science as a truth maker to expertise, and ask the question: Who do we think has expertise? When we ask a question and we want some advice on something, one cannot imagine a world in which one doesn't value the advice of someone who has more expertise rather than someone who has less. If you try to imagine a world in which you don't value people who have more expertise, it's crazy. You wouldn't be interviewing me to ask what I think. You would be interviewing anyone who is walking in this park, because I would have no special expertise in what I am saying, anybody would do. The Third Wave was simply a turning of attention to expertise and experience.

Did Sheila Jasanoff and Brian Wynne's response to the paper surprise you? Do you think any of their criticism is justified?

Their response to the paper totally surprised us. Robert Evans and I thought of the paper as something fairly small. We thought people would appreciate the point and carry on roughly as before. We were completely astonished by the responses of Wynne and 
Jasanoff, both by the fact of the responses and by the content of the responses, which are essentially political. Sheila Jasanoff says things like "oh, why should we take any notice of Collins when the whole world is moving in the other direction; towards democratization of science and expertise?" That's not an academic argument; it's a simple, straightforward piece of politics. Arie Rip also wrote a quite sensible critique which has largely been forgotten. It was a normal, academic critique. His was the one we struggled the most with to answer. The others hardly seemed worth answering. They were just political bellowings. We were very surprised about it. But we were very grateful to them as well, because I think if it hadn't been for those responses we wouldn't have done much with the Third Wave. We'd just have gone back doing what we were doing, maybe written some other little papers with the same lines. But suddenly we realized we must be doing something much more important than we thought we were doing. So, that's how the Third Wave started to grow, and it has grown into a very large thing indeed. And here we are in Hungary with a conference based on a grant which emerges from the Third Wave, and it's marvelous.

\section{Contrary to Jasanoff and Wynne's response, Darrin Durant has argued that Rob and yourself, indeed, are democratic, but that you work within a different tradition, that of John Rawls and liberal egalitarianism. Do you agree with his interpretation?}

We certainly agree that there's been nothing undemocratic about what we are doing. It seems bizarre to say so. In fact, I think up till now I've believed that I've lived in a democracy in the UK, and what happens in a democracy you live in is that you vote for politicians every four or five years, a new party comes in, and then you give them a mandate. You delegate them to employ all kinds of experts to make decisions about this and that and the other. Some of the experts are good, some of the experts are bad, but you don't try to make the expert decisions all the time. So nothing seems incompatible about expertise in democracy at all. I very much like Darrin Durant's paper, and I like a lot of Rawls' ideas, but I'm not sufficiently expert in the details of different models of democracy to comment on this in detail. Rob Evans is better at this.

At a conference I recently attended, Brian Wynne said, "Ordinary people should be involved in policy processes". What are your thoughts on this?

He said ordinary people should be involved in policy processes? Well, of course they are. Whenever they vote they decide whether the policy processes that have taken place are good ones or not. They express themselves in that way. I would have no problem with much of what Brian Wynne says. The only thing I object to is the ideas that flow out of the notion of so called 'lay expertise': the notion of ordinary people having as much expertise as so-called experts. There certainly was a time when Brian Wynne was expressing this view, or his followers were expressing this view, and it looked as if the very notion of expertise was going to be dissolved. This I found quite frightening actually. I'm not sure what he believes now, because it is very hard to get Brian to declare in a straightforward way what he believes, what he used to believe, and if he's changed his mind or not. It's not quite clear what his trajectory has been.

\section{What can be done to improve the interaction between scien- tists and policy-makers?}

This is where we get into the actual details. Rob Evans and I have already written a paper in Critical Policy Studies, which gives some kind of vague ideas about how science and policy relate, and now we're working on the details of this. My own view is that it's time that STS Studies stood up and were counted. I think that we in STS - at least some of us - are experts in the nature of science. The greatest experts in the nature of science there have ever been. I'm interested in notion of scientific consensus. It doesn't seem to me you can make policy without this notion. You can't make policy science relate to policy without it. That doesn't mean to say that consensus must drive policy. I think policymakers have to refer to scientific consensus and say "here I'm going with scientific consensus or here I'm going against it." As we express over and over again: The bottom line in all policy decisions are politics. It is always politics, which trumps everything else. But the public has a right to know whether politicians are going with scientific consensus or against it. However, we don't really know what scientific consensus is. The next step that my colleagues and myself want to take in Science Studies is to work out what scientific consensus is. What is a strong scientific consensus and what is a weak one? If we can figure out that, then policymakers will be able to refer to these studies and say: 'this is only a weak scientific consensus, so I'm going to go against it' or 'this is a very strong scientific consensus, I'm going to go against it and here are my reasons for it.' We continually refer back to Thabo Mbeki's decision not to distribute antiretroviral drugs in South Africa to point out that Thabo Mbeki was completely wrong in trying to justify his actions by saying there was a scientific controversy over the safety of antiretroviral drugs. There was actually a very strong scientific consensus over the safety of antiretroviral drugs. Thabo Mbeki would have been quite entitled to say "there's a strong scientific consensus over the safety of antiretroviral drugs, but we are not going to use them in South Africa, because we don't want South Africa to come under the thrall of Western pharmaceutical companies, because we don't want to project an image of South Africa as a disease-ridden, promiscuous society, and because we can't afford it." But he didn't say any of those things, which would have empowered his population to agree with him or disagree with him according to how they voted in the next election. Instead he said, "there's a scientific argument over this." It is not true; there wasn't a scientific argument over this, and social scientists - people who understand the nature of science, could say "at this point in time, Thabo Mbeki, there is no scientific dissensus, there is a very strong scientific consensus that antiretroviral drugs are safe. Even though you can find a big argument over it on the Internet." The skilled social scientist would say "those arguments on the Internet do not represent what the scientific community thinks." 
I read in an article in Nature the other day that you were able to fool physicists into thinking you were one of them. How were you able to pull that off?

This is the notion of interactional expertise. Having spent many years intensively interacting with gravitational wave physicists I learned to speak their language. Out of this came the notion of interactional expertise. What I was doing in that test was demonstrating my interactional expertise in gravitational wave physics - which has probably faded quite a lot by now. I doubt I could pull of the same trick now. But at that time I understood gravitational wave physics pretty well, as a result of being immersed in the discourse of gravitational wave physicists for so long.

I also heard something about physicists evaluating your answers and comparing them to other physicists' answers, in a similar way you're doing with the Imitation Games.

That's right. We played an Imitation Game, which I pretended to be a gravitational wave physicist and other gravitational wave physicists gave answers. Nine people evaluated the dialogues and tried to guess who is who. Seven said they couldn't tell who was who and two said I was the genuine physicist.

Tell me about your new project, the Imitation Game. How does it relate to your earlier work?

It was just that I was interested in this notion of interactional expertise. It is a new concept and it is what you get by being immersed in the discourse of a specialist community. Even though you don't take part in their activities, we argued that you could acquire expertise and make judgments which were as good as an expert. To see whether this was true, we used a modification of the Turing test, called the Imitation Game. We asked people who were interactional experts to compete against genuine contributory experts, and then we had other contributory experts trying to decide whether they could tell the difference. What we showed is that you can't tell the difference. Now we have this wonderful European Research Council advanced grant where we're using the Imitation Game idea to test for the extent to which regular populations in a society understand minority populations, such as gays, or in very religious societies whether secular people can understand religious people. We play about 200 Imitation Games in each location and we use the numerical results as a gage of the degree of integration of one community with another, or degree of understanding of one community by another. We are doing this all over Europe and also in South Africa. It's one of the spinoffs of the Third Wave - something which we could never have foreseen.

\section{What is next for Harry Collins? What are you working on?}

I've just completed a book manuscript called Are We All Experts Now? It is a semi popular book about the relationship between ordinary people and expertise. It argues, of course, that we're not all scientific experts - except in some narrow respects. I've been completing responses to critics on a number of fronts, especially my book Tacit and Explicit Knowledge; that seems to have been discussed in at least two or three specialist journals. I'm still conducting my Wave Two gravitational wave physics study, and another book on gravitational wave physics is coming out at the end of 2013. I'm also completing a manuscript called 'Elective Modernism', which is another way, or another move, you might say, in the Third Wave of Science Studies. It attempts to argue that we should value science, not for its results but for its moral values. It has a slight Mertonian flavor, but it's more radical than Merton. Merton said we should value the values of science because they were so efficacious. We are saying that you should value the values of science because they are just good in themselves - and that's it.

The must-ask question: If money, time, space, and institutional requirements weren't an object, what would be your dream research project?

I don't know. I don't sort of work that way. I think I'm doing everything I want to do as it is, and I don't really have a dream research project. 